\title{
SOY UNA CRIATURA
} Giuseppe Ungaretti (1888-1970)

Como esta piedra

del S. Michele

tan fría

tan dura

tan enjuta

$\tan$ refractaria

tan completamente

desanimada

Como esta piedra

es mi llanto

que no se ve

La muerte

se paga

viviendo 